\title{
EL ANIMAL DE LA IMAGINACIÓN: PENSAR ESCRIBIENDO Y ESCRIBIR PENSANDO
}

\author{
Nadia Prado \\ Universidad de Chile \\ nadiacamposprado@gmail.com
}

Texto leído en el teatro La Memoria el 4 de junio de 2013, con ocasión de la presentación del libro Catástrofe y trascendencia en la narrativa de Diamela Eltit, del filósofo Sergio Rojas (Sangría Editora, Santiago de Chile, 2013, 272 páginas).

Lo que arranca al horror de su contexto y lo vuelve más horrible es la escritura

Sergio Rojas

Asistimos a una conversación, conmovidos en esa fluctuación para inaugurar la propia. Pienso y escribo, escribo y pienso, y al hacerme a ello me digo: Eltit piensa escribiendo y Rojas escribe pensando. Cuando esa oscilación temporal cae en su peso es arrastrada por su propio lastre y además invierte su sentido para reanudarse. Así entiendo el hacerse a que Rojas trabaja en Catástrofe y trascendencia en la narrativa de Diamela Eltit. En esa noción resuena lo que rodea, vive y obra frente a Eltit y a través de ella. La escritura y el que escribe se hacen a la catástrofe. Esta noción, más específicamente, refiere al hecho "de que algo deviene en otra cosa", "leer significa (...) hacerse a la dificultad de una escritura" (Rojas 29) y, con Deleuze, comprendo que se trata de reproducir algo totalmente distinto en el sentido "de captura de código, plusvalía de código, aumento de valencia, verdadero devenir" (Deleuze 16).

Rojas sostiene, al leer Lumpérica, que "se trata de una cotidianidad (...) acechada por una realidad en la que todo se ha vuelto incierto y en la que los comportamientos rutinarios son simplemente lo que ha quedado después de una catástrofe" (46), donde la plaza es el recurso para hacerse a la escritura. Pienso este "carácter autosuficiente" (140) de la escritura y, a la vez, dependiente de sí misma, en tanto nos resistimos como el pez al anzuelo. Me pregunto ¿qué es esto que leemos e interpretamos? No es otra cosa que lo que le acontece al pensamiento, sopesar esa palabra que nos es dirigida, el 
"reclamo de la obra" (Derrida 2009)1, afán de trascendencia en medio del derrumbamiento absoluto. Sobre el peso de las cosas, el lenguaje vuela. Más allá de todo, en el eclipse del sentido (Nancy 9), ir hacia el mundo para el despliegue del lenguaje, la trama y el entorno. No se trata de escribir acerca de sino en, inscribir la realidad en el sentido. Es lo que se presiente como incerteza del terror cuando Sergio Rojas lee Lumpérica, o cuando sabemos de la decadencia y la alienación en la memoria del continente en Por la patria. Rojas entiende el carácter trascendental del verosímil allí donde pareciera ser que toda vez emerge en la obra el como si de la realidad, su qué, su cómo y su entrecruzamiento.

La contundente y lúcida narrativa de Diamela Eltit, exigida por esa catástrofe de la subjetividad y gracias a la cual el lenguaje intensifica su reflexividad (Rojas 46), donde todo tiempo ha sido inaugurado por una tragedia y donde todo ha sido afectado por esa estabilidad sin fin de la destrucción. Este libro se hace a esta poética de la devastación y a su inédita radicalidad (Rojas 20), cifrando el universo significante en expansión y comprendiendo el rumor de la lengua que en ella acontece. Le hace lugar a las imágenes, las trae múltiples veces, en la desposesión del sujeto.

¿En qué tiempo se vive después de una catástrofe?, ¿en qué tiempo escribimos? Somos asediados, con retardo, por lo irrepresentable. Sergio Rojas lee escribiendo esos límites de la representación explorados por Eltit. La página se afecta de las escenas y visiones de esta escritura: como si escribiera un diario, ensaya y ocupa el lugar de las novelas (la plaza, las barricadas, el útero, la habitación, las visiones, la cama, el sur, el hospital). Esa es la potencia que orienta al sujeto hacia el lenguaje y a la embestida que este encuentro conlleva. Haber sentido, haber presenciado, haber vivido prolonga el tiempo hasta hoy. En un débil acaso, solo como posibilidad de redimir los segundos del hundimiento total. Sergio Rojas comprende el ritmo con que Eltit lee, no solo un trazo o una trama, sino el intervalo mismo que atraviesa el laberinto de la alteridad de su narrativa, que se encuentra y desencuentra con un usuario alienado por la presencia del otro, ese animal pensante que se mueve en las novelas y que va aumentando la potencia del lenguaje en este ejercicio de lectura que piensa a través de. Se trata-así entiendo su lectura de Vaca sagrada y de Los vigilantes- de una destrucción que moviliza esta relación. Algo nos empuja a pensar, algo nos impele al lenguaje. Sergio Rojas sopesa el lenguaje, toca el peso de cada palabra, esa es la exigencia en este diálogo. El muro biológico que frota los cuerpos en El cuarto mundo, "lo otro de lo propiamente social" (Rojas 82), ese "límite imaginario" (Rojas 82) en el que el sujeto más que ser expulsado es infiltrado. El espacio de lo otro sería entonces esta alteridad en el seno del origen y cuyo límite promete ser franqueado en el por-venir, en cuanto el frote es la ilusión de independencia. No hay invasión total, sino intento de expulsión.

Al leer El padre mío, anota: "[L]a catástrofe de la subjetividad hace síntoma en el lenguaje" (229). Y esta catástrofe no es respecto o acerca del otro, sino en el otro, porque la ética sería el cara a cara con el otro, pues el otro siempre se me devuelve como

1 Gadamer es quien habla de este Anspruch de la obra, su reclamo e interpelación exigente consignado por Derrida en Carneros. 
lenguaje y es su palabra perdida, cuando su cuerpo se ha derrumbado por completo, lo que debo traer. Esta exposición a la alteridad de lo desconocido que lee Rojas tiene esta ética, la de la afectación. Alteridad y mismidad radical que suma, hiere y lame a otro, el cuerpo desujetado, alterado y en su variabilidad ilimitada. Pienso en ese tirar y lastrar del que habla Gadamer, e intuyo que este es un ser que conmemora a otro, que no puede olvidar esa solicitud, esa afectación y ese ingreso sensible del mundo en el sujeto. Toda imaginación, todo límite, todo deseo, todo fin más allá de su fin es leído con minuciosidad. Quizá "la ficción del límite" es "incorporar" al mundo lo que ha debido quedar fuera, los signos que se desbandan, se insubordinan, donde no hay -dice Rojas"una correspondencia indexial" (105). Un límite, un umbral se ha olvidado o de ellos nunca se ha tenido noticia. Este sería "[e]l borde interno del fin" (Rojas 101), el borde del sentido y de la lengua; aquel contra, con y en el cual pensamos. Y ello es leer escribiendo; deseo, pensamiento, donde la sangre es "el recurso privilegiado de la imaginación" (Rojas 106). Imaginar, sangrar, escribir, sería entonces, como señala el libro, "poner en obra la exigencia de la imaginación" (Rojas 106). La historia es contenida, portada y retenida por la imago (Rojas 107). Y esta intensidad convierte la historia en una cifra. Aquello, entre otras cosas, el libro de Rojas da a pensar: la cifra donde el sentido se oculta y se aplaza indefinidamente, la manera en que su aparecer se difiere o se desencadena, de modo incluso provisional y tentativo. Poner en obra de la imaginación, un taller que se duplica entre Rojas y Eltit. La fantasía, el taller de la imaginación crece, se ejecuta haciendo que la imagen viaje cargada, grave, siempre en vías de liar y desliar el pero ahora de toda escritura.

El autor deja una seña para su lectura de la catástrofe en la narrativa de Eltit cuando se pregunta ¿por qué se escribe? Y responde: "En el inicio hay siempre algo que pasó" (Rojas 16). Este es otro de sus aciertos: señalarnos que Eltit "reflexiona y extrema la devastación (...) desde la que ha surgido la subjetividad" (Rojas 17), allí donde nuestras representaciones guardan un "fondo impresentable" (Rojas 17). Ese acontecimiento, ese algo que ocurrió en el lugar de aquello que ya no entendemos o no vemos, es decir, el mundo. Esta intensidad de lo Real, dice Rojas, dirige al sujeto hacia el lenguaje, para poder representarse el mundo y que las palabras nombren, que la escritura sea la búsqueda "entre el después de lo Real y el aún-no del mundo" (Rojas 18).

En este pensar que introduce Rojas en su lectura de Eltit, entendemos que el deseo encapsulado en el cuerpo hace que este padezca ese límite que desea ir más allá, revelando la condición hipertélica del deseo. Se trata de la anatomía, que en tanto encierro se desborda en imaginación escribiendo. Anota Rojas, "el animal encerrado es la imaginación misma como deseo" (115). Aparece, junto a lo otro, el deseo y el lenguaje. Reciprocidad como lenguaje, trato entre imago y palabra, ser respecto de que se expresa y difiere. Un "cuerpo imaginado por un cuerpo" (Rojas 116). Y es allí donde crece la intensidad, en la ausencia. Sergio Rojas encuentra en esta escritura la hostilidad despertando al “animal de la imaginación” (118). Lo que se imagina allá desde acá. Y desde allá teme el acá. Necesidad de pensar y de escribir a partir de ese en, como el desvelo y el diálogo desesperado que dirigimos a la lengua del otro y al lenguaje.

Por otra parte, Rojas señala que la escritura neobarroca de Eltit "tiene un sentido político" (15) y que "es una diferencia en la literatura" (15), puesto que cuestiona la 
posibilidad de comprender unívocamente la realidad y reflexiona críticamente sobre cualquier intento del discurso para invisibilizar las operaciones significantes. Y luego retoma esta idea para vincular la obra de Eltit con la noción de lo impolítico de Roberto Esposito, en tanto sería "una intensificación y radicalización de la política en la medida en que está encerrada por la identidad consigo misma" (32) o, como dice el filósofo italiano, confinada en su "desnudo ser lo que es" (15). Rojas lee el carácter impolítico en la escritura de Eltit en esta imposibilidad, en este interior devastado, en este dolor, en y entre nosotros, que cuestiona el nihilismo pasivo y que hace a esta escritura hablar para luego textualizarse. Así, la importancia de esta nueva lectura radica en que entiende "la operación de trascendencia de la escritura como textualización de la catástrofe, y en vez de buscar simplemente una salida -al modo que se buscaría una buena historiapasa a través de ella sin que necesariamente alcance un afuera (...). Escribir no es salir sino pasar por, atravesar" (242-243). Sergio Rojas solo puede hablar de esta escritura contundente haciéndose a ella, es decir, escribiendo; solo un lenguaje afectado por otra afectación puede pensar o llegar a decir pensando.

Leyendo Impuesto a la carne nos enfrenta a un residuo de eso que llamamos sí mismo y que, estando fuera de sí, ya no es capaz de alojar "el desmesurado contenido de la muerte" (219). Para contener este dolor, este todo sigue, para soportar la "devastación del mundo por efecto de una dolorosa subjetividad en expansión” (238). Ninguna palabra, ninguna imagen, ningún sonido, ninguno de nosotros tiene derecho, si no sabemos lastrar ese grito, y aun fuera de sí, cada uno en cada caso, tomar aquello que ha sido arrojado al mundo (esto es, el grito) y darle su lugar, concernidos por ese diálogo que nos dirigimos, acogiendo la lengua del otro. Rojas, leyendo esta escritura que lleva "a la catástrofe del sujeto en el lenguaje" (47), acusa recibo de la comparecencia, en el seno mismo del sujeto, de la desmesura del grito del otro, que evidencia el grito que somos. Esa búsqueda lleva la forma de un dirigirse a, para soportar el espesor y la interrupción del otro y del propio yo. Ir hacia lo que nos excede, aquello que ha expirado y que solo percibimos después de su fin, "elaborar esa anterioridad" (19) en ella, después de ella, pero jamás fuera de ella: este pareciera ser el carácter monádico de la catástrofe que lee Rojas en las novelas del Eltit, cuando nos parece decir que la distancia es la única manera de habitar esa devastación. La escritura, ese lleno singular del tiempo, esa referencialidad extrema que Rojas advierte, en especial en El cuarto mundo, es la distancia que pone el sujeto frente al mundo para poder habitar en medio de él. Solo de esta manera puede obrar esta poética de la devastación, solo puede hacerse $a$ una disposición, a algo que al mismo tiempo de enunciarse se realiza, como una promesa. Entendemos así lo escriptible barthesiano tratado acá, como deseo de escritura, o más bien deseo de lectura-escritura. Y en este sentido, por lo tanto, entendemos: hacerse $a$, encarar, percibir la alteración, resguardarse en el interior de un emplazamiento que expulsa para obrar, para producir y autoproducirse: "atraer la letra hasta la letra sin más rentabilidad que su choque y su infinita combinatoria interna” (Eltit 282). Un sujeto que juega en medio de esta continuidad no simétrica, esto es la infidelidad propia del pensar, un no filiarse porque sí. Se trata de un "deseo de recodo", de "parapetarse allí" (Eltit 281), como ha dicho Diamela Eltit en Signos vitales. Y Rojas anota: "El deseo es la referencialidad extrema de la escritura" (101) que se dispersa. El libro pulsa la textualización de un pensamiento expansivo, en el 
que el mundo, desde su infinita posibilidad de lenguaje, ha sido intimidado, hostilizado y resuelto ante el límite.

Este "trabajo de agotar el lenguaje ha de iniciarse una y otra vez" es lo que Sergio denomina "la emergencia del lenguaje" (27), que hace asomar las palabras y las imágenes, como en Los vigilantes, sin otro que corresponda, haciendo que la escritura se dirija hacia una ausencia, es decir, hacia una presencia más intensa; y esto es lo que habilita la trascendencia, la demora, el no todavía. La salida solo se figura hacia el mundo desde dentro de un mundo. "Soliloquio neobarroco" (18) que emerge disolviendo, dice Rojas. Y agrega: "Nunca hubo otra cosa que lenguaje" (101), "[n]unca hubo otra cosa que escritura" (121 y 139). Lector con el afuera dentro, olvido de sí del sujeto que el autor ve en Los trabajadores de la muerte, cuando la madre es la mujer-madre-espalda que carga y se encorva (Rojas 150). El afuera haciéndose interior, la imaginación en panóptico despliegue. No hay descanso, no hay distracción, llegar al devenir del otro, a las posibilidades de aquello, de su conmoción, de su inquietud, obstáculo y umbral, esto es "a través de [sin alcanzar] un afuera" (Rojas 243).

La alteridad absoluta en las novelas de Diamela Eltit nos empuja y nos hace a su escritura y a la lectura de Sergio Rojas porque, como la autora, él también escribe en esa lectura que interroga una escritura "que conduce al pensamiento encabalgado en los significantes, hacia esa zona en que comienzan a deshacerse las representaciones y con ello (...) nuestra condición de sujetos" (Rojas 30). Lee el desmayo del sujeto, de este sujeto alterado, cuya subjetividad es desbordada en la intensidad de aquello que conocemos como mundo. El lenguaje en esta narrativa, sostiene, es un lenguaje que tiene derecho, precisamente, porque "ha sido afectado por la catástrofe y ha sido alterado por la inhumanidad de la historia en cuyo después nos encontramos" (239). Es ese después, como entrega y eco, luz y sombra de un devenir en el que hoy nos hacemos a esta presentación. Esta lectura de Sergio Rojas corresponde y recoge la segunda vez de toda escritura, para la que siempre falta tiempo, porque el lenguaje en tanto esfera irreductible opera como la constitución de un sujeto siempre preso de una experiencia anterior inmensa que, además, quiere vivir y escribir; y ambas cosas son desde ya demasiado.

El borde del fin es devenir en otra cosa, hacerse a la escritura. Ella pasa y en este paso encontramos un aliento. Somos enviados al lenguaje, pero antes hubo que hacerse $a$ un nuevo comienzo, toda vez que el cuerpo es, como afirma Rojas, "el infinito aún-no del sujeto" (243), en desvelo interminable, donde quizá el sentido aparece desapareciendo y donde la alteridad no es más que laberinto. Hacia ningún lado, hacia todos, hacia el deseo de sentido que se alimenta de su falta, la indiscreta pasión que no quiere perder jamás el ansia que la tensa. Son dos que emprenden una cierta escucha del pensamiento que porta hacia el por-venir, es decir, hacia la escritura. Afán del habla y del hablar del que tira la red y del que lastra, teniéndose el uno al otro. Pensar escribiendo y escribir pensando. 


\section{BIBLIOGRAFÍA}

Deleuze, Gilles y Félix Guattari. Mil mesetas. Capitalismo y esquizofrenia. Valencia: PreTextos, 2002.

Derrida, Jacques. "Carneros. El diálogo ininterrumpido: entre dos infinitos, el poema". Buenos Aires: Amorrortu, 2009.

Eltit, Diamela. Signos vitales. Escritos sobre literatura, arte y política. Santiago: Ediciones Universidad Diego Portales, 2008.

Esposito, Roberto. Categorías de lo impolítico. Buenos Aires: Katz, 2006.

Nancy, Jean-Luc. Lengua apócrifa. Santiago: Cuadro de Tiza Ediciones, 2013.

Rojas, Sergio. Catástrofe y trascendencia en la narrativa de Diamela Eltit. Santiago: Sangría Editora, 2013. 